\title{
Fly ash morphology and surface modification via mechanical activation: A review
}

\author{
Abadi A. G. ${ }^{1}$ 网 Al-Shandoudi L. ${ }^{2}$
}

Received: 30.09.2020

Revised: 27.10 .2020

Accepted: 06.11.2020

\begin{abstract}
Fly ash (FA) F low reactivity, slow hydration reaction and low early strength, restricted its industrial usage to less than 25 wt \%. Ash properties were modified by mechanical activation to achieve higher added value product. The activation depends on the equipment type and their particle size range of milling. This paper reviewed the milling equipment effect on particle size, surface properties, and chemical compositions of activated ash. Increasing in the surface area, pozzolana activity and the reduction of crystalline dense layers of fly ash $F$, leading to microstructure and structural variations which raised the ash industrial applications.
\end{abstract}

Key Words: Fly Ash, F Surface Properties, Mechanical activation, Milling equipment, Pozzolanic activity

\section{Introduction}

Sustainable ash management requires the converting of waste materials as new raw materials for other industries. Silicate or alumino-silicate based raw materials found in fly ash released from thermal power plant are produced in enormously large amounts worldwide, and its disposal landfill implies environmental and social problems. However, the requirements of these kinds of materials are extraordinarily heterogeneous. Therefore, it is imperative to control and adjust their characteristics, to enhance the overall performance. The amendment can be reinforced by usage of few approaches such as mechanical, thermal or chemical activation. Coal fly ash (CFA) dense glassy surface layer, chemically stable, protects the active inner constituents, which generates low reactivity particle surface. Ash comprises of porous, spongy and amorphous particles. The reliability of the FA can crumble to encourage its chemical activity if the glassy chain, which incorporates $\mathrm{Si}, \mathrm{AL}$ and low carbon, is exposed to activation methods. Activation methods are utilised to control and alters the ash characteristic for specific persistence in some fields. FA applications are often expanding if Author's Address

${ }^{1}$ Engineering Department, Chemical Engineering Unit, University of Technology and Applied Science -Suhar-Oman

${ }^{2}$ Science Department University of Technology and Applied Sciences-ALRustaq P. O. BOX: 329,PC:10 AL Rustaq, Oman E-mail.: afafg.soh@cas.edu.om the ash has larger specific area and finer particle (Babel, 2003). One of these methods is the grinding mechanical activation (fig. 5), which enhances the reactivity of fly ash through three approaches: a) Mechanical dispersion (size reduction), Figure 1, where the advanced reactivity is the end result of the higher surface area exposure, b) Surface activation, the place that mechano-chemical reactions appear on the particle surface, and, c) Mechano-chemical activation, internal components of the particle radically change to different structures (Gabor, 2016).

\section{Activation of Fly Ash by Milling}

The main milling equipment accustomed to grind ash into smaller particle size are; rod milling, ball milling, vibration milling, and electromagnetic mill as mentioned in Table 1. Ball milling consists of a rotating hollow cylinder, partially filled with balls. The material (to be ground), is fed in via a hole trunnion at one point and an equal trunnion at the opposite end, to enable the product to go through it. The outlet is typically sheltered with a rough shade to rest the break of the balls. It is frequently loaded with particulates $30 \%-40 \%$ of its size (Coulson and Richardson, 2002). Rod mills are comparable to ball mills, with log rods for grinding media, it received feed up to about $50 \mathrm{~mm}$ (Brook, 1991) Figure 2. Vibration mill is occupied to $80 \%$ of its capacity with porcelain or stainless-steel balls. During milling, the whole physique of the mill undergoes a very low and frequent vibration, which is generated through an eccentric motor and dimension discount takes 

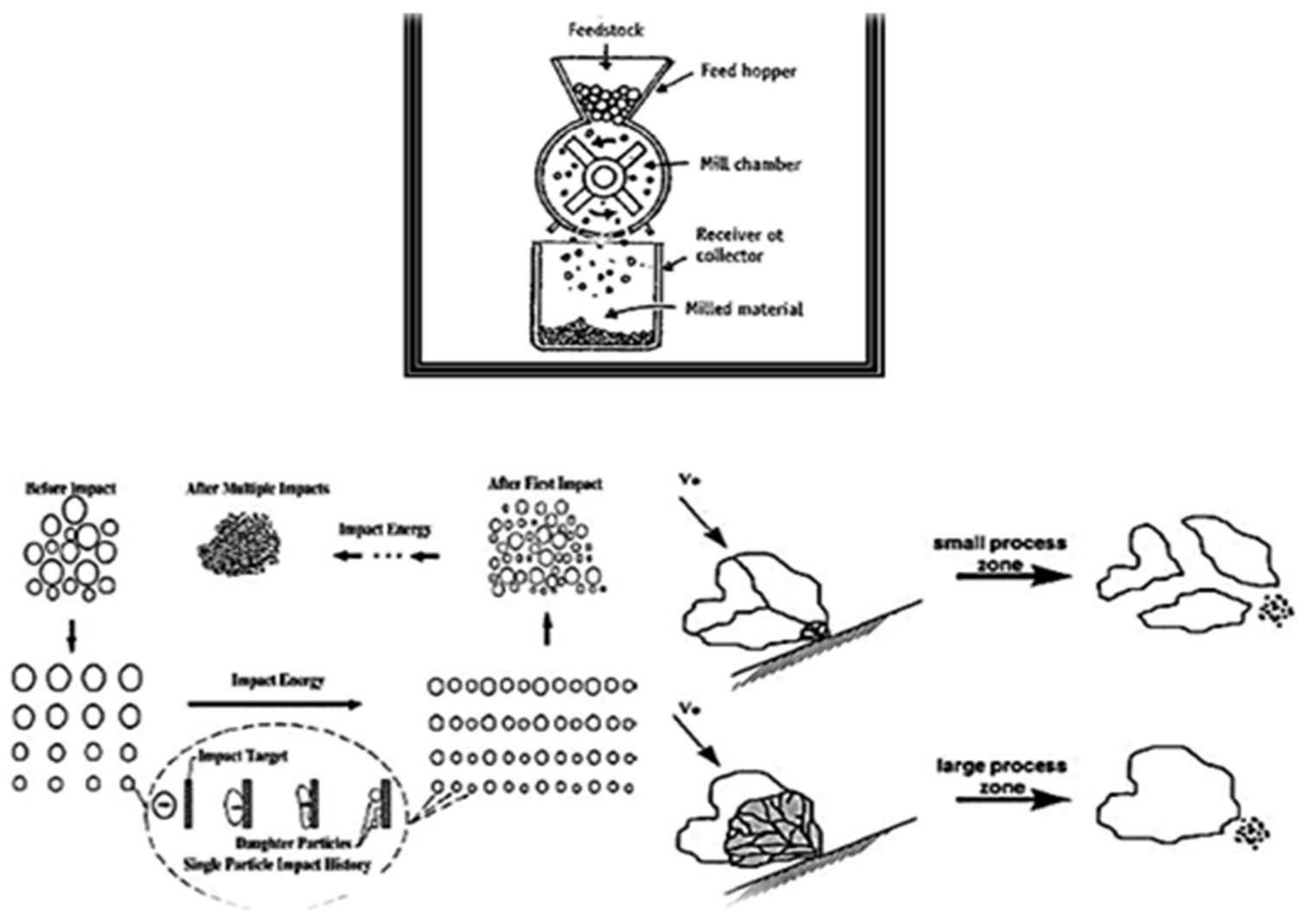

Figure 1. Milling Size Reduction Mechanism - (Sushant and Archana, 2013).

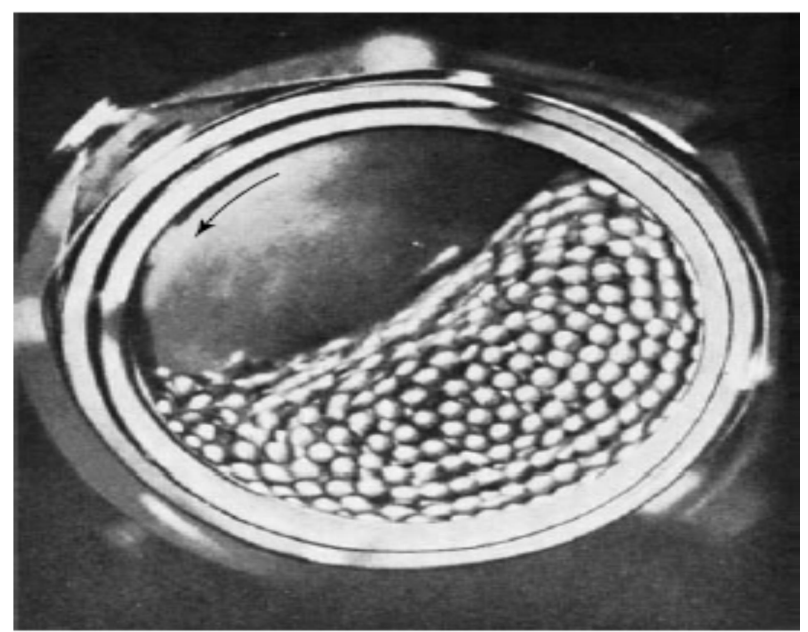

Figure 2. Ball Mill (Coulson and Richardson, 2002).

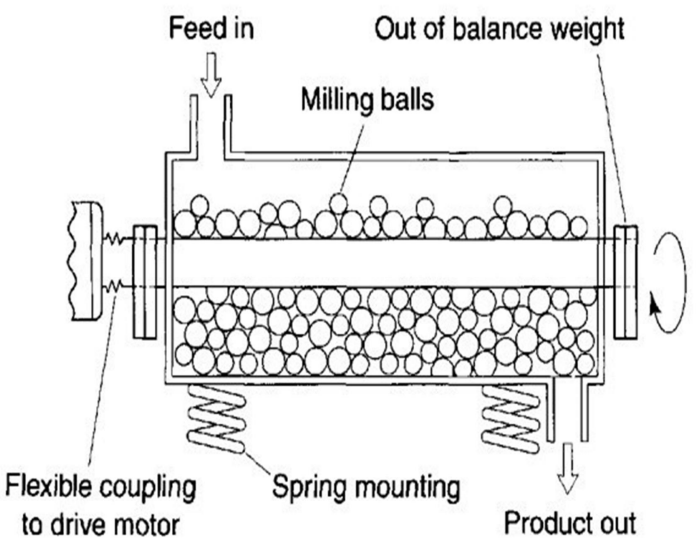

Figure 3. Eccentric Vibratory Mill (Brook, 1991).

grinding media (small rods), which cross in rotating electromagnetic field (Xue et al., 2004). Milling or grinding reduces the size of the ash by transforming large, spherical particles into smaller, irregularly shaped particles, which subsequently negatively affects rheology. Grinding consumes more energy 
to obtain fine particle size distribution, and there are size limitations. The advantage of grinding is that the entire grinding volume only contains the defined particle size distribution, not the fine and coarse particle size distributions. For particles of $50 \mu \mathrm{m}$, the energy required to grind the fabric to the specified size follows the Von Riddinger grinding law (Equation 1), while the particle size greater than $50 \mu \mathrm{m}$ follows the Bond grinds law (Equation 2):

For the particle size $<50 \mu \mathrm{m}$,

$$
\mathrm{W}_{\mathrm{R}}=\mathrm{C}_{\mathrm{R}} / \mathrm{d}_{\mathrm{E}}-1 / \mathrm{d}_{\mathrm{A}}
$$

For the particle size $>50 \mu \mathrm{m}$,

$$
\mathrm{W}_{\mathrm{B}}=\mathrm{C}_{\mathrm{B}} / \mathrm{d}_{\mathrm{E}}-1 / \mathrm{d}_{\mathrm{A}}
$$

Where,

$\mathrm{W}_{\mathrm{R}}, \mathrm{W}_{\mathrm{B}}$ : Grinding work $(\mathrm{kJ} / \mathrm{kg})$.

$\mathrm{C}_{\mathrm{R}}, \mathrm{C}_{\mathrm{B}}$ : Grinding coefficient

$\mathrm{d}_{\mathrm{E}}, \mathrm{d}_{\mathrm{A}}$ : Sizes of the ground material

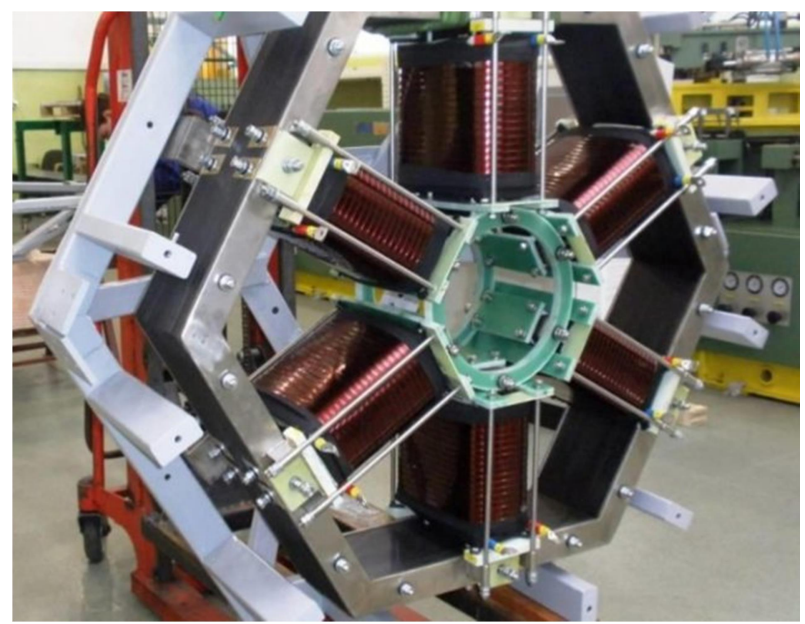

Figure 4. Electromagnetic Mill - (Wolosiewicz-Glab et al., 2016).

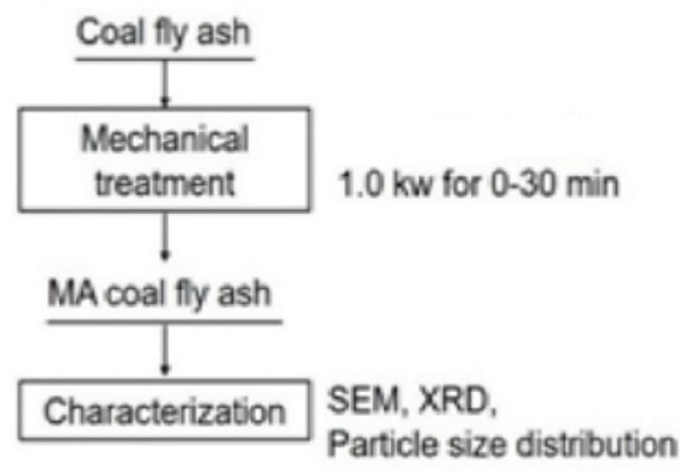

Figure 5. Flow Chart of the Mechanical Activation Methodology (Matsuoka et al., 2019)
Milling changes many physicochemical properties of fly ash. The structure of the material becomes disordered. That creates surface defects. In other words, metastable forms can be found (Palomo et al., 1999). This lead to the change in the structure and surface properties, depending on the activation procedure and application needed. It will affect the dispersibility of the particle size distribution (PSD), specific gravity (SG) and specific surface area (SSA), morphology and mineralogical composition (Gabor, 2016). Milling mechanical activation is designed for the destruction of the long-range order intermetallic phase and creation of either a disordered intermetallic or an amorphous phase. In addition, the mechanical activation improves the pozzolanic activity of fly ash (Bouzoubaa et al., 1997; Varma et al., 2013; Palomo et al., 1999; Paya et al., 1995).

This paper reviews the surface changes of Class $F$ fly ash, when mechanically activated, in particular the specific surface, specific density, mineralogical phases and reactivity properties. Different mechanical activation ways are used to control fly ash characteristics and its application.

\section{Materials and Methods \\ Class F Chemical Composition}

Fly ash (FA) particles are generally spherical, with a size ranging from $0.5 \mu \mathrm{m}$ to $100 \mu \mathrm{m}$. Class $\mathrm{F}$ ash contains more than $70 \%$ of $\mathrm{SiO}_{2}, \mathrm{Al}_{2} \mathrm{O}_{3}$ and $\mathrm{Fe}_{2} \mathrm{O}_{3}$ and less than $10 \% \mathrm{CaO}$. FA shows an existence of amorphous glass, mullite, quartz (crystalline silica), hematite and small amounts of lime. The intensity of quartz with mullite forms a chemically stable and dense layer (Gabor, 2016).

Fly F silicate, or silicate -aluminate (Pozzolana Material) bosses a small or absent self-hardening, which reduces its utilization to remarkable limit (Rosenberg, 2020). The hydrated silicate in fly ash develops the strength while the lime fills the voids, by forming $\mathrm{CSH}$, give the mixture the same consolidation properties as Portland cement. The reaction of fly ash and lime in concrete increases the strength .But by adding the original F-class flight ash to $15 \%$ to $25 \%$ in concrete (Varma et al., 2013), decreasing the cements activity was observed (Varma et al., 2013; Sanytsky et al., 2018) due to the low quantity of $\mathrm{CaO}$. The pozzolanic activity of fly ash increases the 
compressive strength in future stages (Patil and Anandhan, 2015), but low strength was observed at the early curing time. The microstructure of fly ash $F$ before one year on curing exhibits a copious amount of un-hydrated spherical fly ash particles (Nalbantoglu, 2004). To solve the Class F drawback in order to achieve sufficient strength throughout the total stages of curing, it is appropriate to mend the ash surface and reactivity by applying activated methods (Akinrotimi et al., 2015).

\section{Experimental Methodology}

Mechanical activation changes the physical and chemical properties (particle size distribution, specific surface area (SSA), crystal phase composition). The particle size (PS) distribution can be determined by dry or wet sieving, sedimentation or laser scattering methods (Gabor, 2016). Specific surface area (SSA) of solids is determined by the BET (Brunauer, Emmett and Teller), which is commonly used to evaluate the gas adsorption data and generate a specific surface area result expressed in units of area per mass, (Gabor, 2016). Chemical composition of FA can be determined by the Energy Dispersed X-ray analysis (EDX) (Akinrotimi et al., 2015, 2015; Saha, 2018; Paul et al., 2007). The structure of the material can be predicted by Fourier Transform Infrared Spectroscopy (FTIR) in transmission mode. X-ray diffraction (XRD) technology is used for mineral phase analysis. The morphology and particle shape of the material can be studied by optical or scanning electron microscope (SEM) or transmission electron microscope (TEM) (Gabor, 2016).

\section{Results and Discussion}

The paper reviewed the effect of mechanical activation applying types of equipment. Many parameters within a lot of industrial applications had been reviewed in Table 1 . The necessary per treatments and the studied factors helps the researcher in this field to have summarized view about the mechanical activation research and their changes in fly F properties.

Changes in particle size and Specific density

The milling process can be divided into three phases. The first phase is the initial grinding phase, where the increase in fineness is very obvious, and the time is 0 to 30 minutes. The second phase is the development and grinding phase, in which the increase in fineness slows down, and the time is about 30 minutes to 50 minutes. The third phase is the delay time, which is about 50 minutes to 70 minutes, in which the fineness no longer increases or sometimes decreases a little. This is because the particles are so fine that they cluster together under the action of electrostatic forces (Nalbantoglu, 2004). These results are compatible with the remarks in Table 2 (Helaand Orsakova., 2013; Patil and Anandhan, 2012; Kumar et al., 2007; Hela and Bodnarova, 2013). It should be considered that the product of the mechanical activation (SSA, PS) depends on the type of activation device used. Akinrotimi et al., (2015) point out that simple grinding equipment (Rod Mill) can only effectively grind rough materials, but not for fine materials less than $40 \mu \mathrm{m}$. Sanytsky et al. (2013) used the electromagnetic mill to obtain ultrafine fly ash contents $\leq 20 \mu \mathrm{m}$ (more than 90\%). Large amount of particles smaller than $1 \mu \mathrm{m}$, consisting of spherical silica-alumina grains which contain large amounts of alkali metals (Patil and Anandhan, 2012).

During the grinding process, the increase in specific gravity was recorded. Obviously, 50 minutes of grinding is a critical point, which means that the specific gravity will increase rapidly before this point, and the specific gravity will increase more moderately after this point. However, the specific gravity eased after 50 minutes of grinding. That is because the fineness of FA is reduced at this stage (Palomo et al., 1999). Fineness enhanced the specific gravity rise and this elaborated the increase in cement mortar density when 25 percentages of cement were replaced by milled fly ash, Shows that the upgrade of the particle filler of the mortar combines a finer particle size (Hela and Bodnarova, 2013). For concrete application, the slump increased when milled fly ash added to the concrete admixture .The higher the slump, the higher workability of concrete, (Kumar et al., 2007). Researchers have found that $50-60 \mathrm{wt} \%$ of activated fly ash can be used to replace activated fly ash with higher strength or equivalent to commercially available cement (Subhash et al., 2014). For environmental protection considerations, activated F fly ash can be used substitute for cement in concrete because it improves workability, 
Fly ash morphology and surface modification

Table 1. Parameters affected the Activated Fly Applications.

\begin{tabular}{|c|c|c|c|c|c|}
\hline $\begin{array}{l}\mathbf{N} \\
\mathbf{0}\end{array}$ & References & $\begin{array}{l}\text { Milling } \\
\text { Machine }\end{array}$ & Pre Treatment & Parameters studied & $\begin{array}{l}\text { Affected } \\
\text { Application }\end{array}$ \\
\hline 1 & $\begin{array}{l}\text { Akinrotimi et } \\
\text { al., (2015) }\end{array}$ & Rod Mill & -------- & $\begin{array}{lr}\text { Milling } & \text { time- SSA ,SG } \\
\text { and } & \text { comprehensive } \\
\text { strength } & \end{array}$ & Mortars \\
\hline 2 & $\begin{array}{l}\text { Hela and } \\
\text { Bodnarova } \\
(2013)\end{array}$ & Ball Mill & $\begin{array}{l}0.9 \mathrm{wt} \% \text { acrylic } \\
\text { plasticizer to reach } \\
\text { require conistency }\end{array}$ & $\begin{array}{l}\text { Milling time- surface } \\
\text { area- } \\
\text { Comprehensive strength }\end{array}$ & Concrete \\
\hline 3 & $\begin{array}{l}\text { Sharma et al. } \\
(2015)\end{array}$ & Ball Mill & 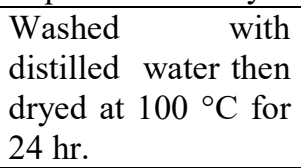 & $\begin{array}{l}\text { Milling time - chemical } \\
\text { compositions -crystalline } \\
\text { phase }\end{array}$ & $\begin{array}{l}\text { solid acid catalyst } \\
\text { and catalytic } \\
\text { support materials }\end{array}$ \\
\hline 4 & $\begin{array}{l}\text { Patil and } \\
\text { Anandhan } \\
\text { (2012) }\end{array}$ & Ball Mill & $\begin{array}{l}\text { Washed with } \\
\text { distilled water then } \\
\text { dryed at } 100{ }^{\circ} \mathrm{C} \text { for } \\
24 \mathrm{hr} \text {, then a } \\
\text { magnetic separation } \\
\text { carried out. }\end{array}$ & $\begin{array}{l}\text { Milling Time-Crystal } \\
\text { size- } \\
\text { Morphology }\end{array}$ & Nanoparticles \\
\hline 5 & $\begin{array}{l}\text { Kumar and } \\
\text { Kumar (2011) }\end{array}$ & $\begin{array}{l}\text { Eccentric } \\
\text { Vibratory Mill }\end{array}$ & $\begin{array}{l}\text { (6 M)sodium } \\
\text { hydroxide ((98\% } \\
\text { purity) used as } \\
\text { alkaline activator }\end{array}$ & $\begin{array}{l}\text { Milling time } \text {-surface } \\
\text { area, Geopolymeration } \\
\text { reaction }\end{array}$ & Geopolymer \\
\hline 6 & $\begin{array}{l}\text { Sanytsky et al. } \\
\text { (2013) }\end{array}$ & $\begin{array}{l}\text { Electromagnetic } \\
\text { mill }\end{array}$ & $\begin{array}{l}\text { Polycarboxylate } \\
\text { type } \\
\text { superplasticizer was } \\
\text { included in } \\
\text { cementitious } \\
\text { systems as modifier }\end{array}$ & $\begin{array}{l}\text { Milling time-Pozzolana } \\
\text { reactivity- Workability- } \\
\text { Comprehensive strength }\end{array}$ & $\begin{array}{l}\text { Ultrafine fly ash } \\
\text { in concrete }\end{array}$ \\
\hline
\end{tabular}

pumpability, cohesion, surface finish, ultimate strength and durability. For geopolymers, the fineness of fly ash plays an important role in improving its performance. The higher workability, the higher strength in early duration of geopolymerization reaction (Patankar et al., 2012; Hela and Bodnarova, 2013).

\section{Change in Specific Area and Reactivity}

Rudolf Hela and Denisa remarked that the grinding in Ball mill for Class $F$ fly ash increased the specific surface area with increasing milling time (Sharma et al., 2015) Other authors represent the similar outcomes, using BET model, where the variation in BET of fly ash with different milling time increased marginally (Sharma et al., 2015; Masuda, 2007; Kumar and Kumar, 2011). As mentioned above, the effect of milling device in SSA is shown in Table 2. SSA increase using ball mill, eccentric vibratory mill and electromagnetic mill in succession. Attrition mill had an effect on the increase the fly reactivity by $11 \%$ greater than using a vibratory mill in the geoplimeraization application (Hela and Bodnarova, 2013; Kumar et al., 2007). Gabor, (2016) considering the particle shape of F fly ash. Compared with fresh fly ash with mostly spherical particles, the surface of the particles is more uneven and rough, with irregular shapes. This leads to an increasing of dislocations, the disclosure of the active surface and subsequently the surface reactivity (Patil and Anandhan, 2012; Kumar and Kumar, 2011). Patil and Anandhan (2012) found that milling of fly ash affects the surface properties and geopolymer reactivity. Heat evaluation peak as an indicator for an attribution to geopolymerisation shifted to low intensity, which indicates an increase of fly $F$ reactivity and that the geopolymerisation reaction can be applied at ambient temperature using mechanically activated fly ash.

\section{Changes in Mineralogical phases}

The general characteristic mineralogical phases in fly ash are quartz, mullite, lime and hematite, (Gabor, 2016). During the process of mechanical activation, the energy influences directly 
Table 2. Main results and Improvements of Mechanical Activated Fly Ash F.

\begin{tabular}{|c|c|c|c|c|}
\hline No & References & $\begin{array}{l}\text { Parameters / } \\
\text { Time }\end{array}$ & Noted Results & Observations \\
\hline 1 & $\begin{array}{l}\text { Akinrotimi } \\
\text { et al., (2015) }\end{array}$ & 0 and $8 \mathrm{hr}$ & $\begin{array}{l}\text { - } 31 \% \text { reduction in PS for coarse } \\
\text { particles. } \\
\text { - } 20 \% \text { increase in strength }\end{array}$ & $\begin{array}{l}\text { - Specific gravity increases, } \\
\text { with reduction of PS } \\
\text { - HVFA gained higher } \\
\text { Strength } \\
\end{array}$ \\
\hline 2 & $\begin{array}{l}\text { Hela and } \\
\text { Bodnarova } \\
(2013)\end{array}$ & $\begin{array}{l}0,20,45 \text { and } \\
75 \mathrm{~min} \\
40,60 \mathrm{~min}\end{array}$ & $\begin{array}{l}\text { - } \text { SSA increased by } \\
25 \%, 60 \%, 88 \% 113 \%, 140 \% \text {. } \\
\text { - } 40,60 \mathrm{~min} \text { milling gave the } \\
\text { highest workability. }\end{array}$ & $\begin{array}{ll}\text { - } & 25 \% \text { fly ash replaced } \\
\text { cement } & \\
\text { - } & \text { Higher concrete slump . } \\
\text { - } & \text { Higher comprehensive } \\
\text { strength initiated in } 40 \mathrm{~min} \\
\text { for ninity days }\end{array}$ \\
\hline 3 & $\begin{array}{l}\text { Sharma et al. } \\
\text { (2015) }\end{array}$ & $\begin{array}{l}5 \mathrm{hrs} \\
10 \mathrm{hrs} \\
15 \mathrm{hrs}\end{array}$ & $\begin{array}{l}\text { - } \quad 6 \% \text { increase in silica oxide } \\
\text { - } 5 \% \text { decrease in Alumina oxide } \\
\text { - } 26.8 \% \text { increase in SSA }\end{array}$ & $\begin{array}{l}\text { - Decreases crystal size and } \\
\text { the crystallinity of the fly } \\
\text { ash. } \\
\text { - increase in, amorphous } \\
\text { nature, specific surface area } \\
\text { and surface roughness }\end{array}$ \\
\hline 4 & $\begin{array}{l}\text { Patil and } \\
\text { Anandhan } \\
(2012)\end{array}$ & $\begin{array}{l}0,10,20,30,40, \\
50 \text { and } 60 \mathrm{~min}\end{array}$ & - $75 \%$ reduction in crystal size. & $\begin{array}{l}\text { - Peak intensity increased } \\
\text { with as an evidence of } \\
\text { breaking down in quartz } \\
\text { structure }\end{array}$ \\
\hline 5 & $\begin{array}{l}\text { Kumar and } \\
\text { Kumar (2011) }\end{array}$ & $\begin{array}{l}0,5,10,20,30, \\
45,60 \text { and } 90 \\
\text { min }\end{array}$ & $\begin{array}{l}\text { Increase in } \quad \text { SSA } \\
: 48.5 \%, 55 \%, 75.6 \%, 139 \%, 141 \%, 16 \\
5 \% \\
\text { Geopolymerisation reaction started } \\
\text { after 32 hrs, for } 45 \text { min milling } \\
\text { samples }\end{array}$ & $\begin{array}{l}\text { - } 40 \text { to } 60 \mathrm{wt} \% \text { of the total } \\
\text { cementitious materials. } \\
\text { - The heat evaluation peak } \\
\text { shifted towards lower time } \\
\text { and its intensity increased } \\
\text { indicating increased } \\
\text { reactivity of fly ash. }\end{array}$ \\
\hline 6 & $\begin{array}{l}\text { Sanytsky et al. } \\
\text { (2013) }\end{array}$ & $\begin{array}{l}0,5,10 \text { and } 15 \\
\min \end{array}$ & $\begin{array}{l}\text { Interaction with } \mathrm{Ca}(\mathrm{OH})_{2} \text { increased } \\
\text { by } 31.8 \% \text {. } \\
\text { - } 45.5 \% \text { increase in strength for } \\
\quad 90 \text { days. } \\
\text { - } 6 \% \text { increase in workability. }\end{array}$ & $\begin{array}{l}-20 \% \text { is the optimum cement } \\
\text { replacement The interaction of } \\
\text { ultrafine fly ash with } \mathrm{Ca}(\mathrm{OH})_{2} \\
\text { Increases. } \\
\text {-Increasing the active surface in } \\
\text { 2-3 times. }\end{array}$ \\
\hline
\end{tabular}

the crystal and molecular substructure. Reduction in occurred. The higher the amorphous phases, the crystalline phases was remarked by an increase in higher fly ash reactivity was seen (Sharma et al., silica percentage of crushed fly ash, which enriched 2015). The important IR bands mentioned in Table the present of amorphous phase (Gabor, 2016). 3 , in the normal range of silicon, oxygen and Paul et al. (2007) found that, the crystalline of ash aluminium band. Which changed due to the milling $\mathrm{F}$ ground for 60 hours is significantly reduced (from $35 \%$ to $16 \%$ ) (Gabor, 2016).Paul outcomes showed a destruction in quartz and hematite crystals phase. These remarks also agreed with Patil and Anandhan (2012) which showed a reduction in crystalline phases with milling time increase. Sharma et al. (2015) represented the coexistence of amorphous components after mechanical activation. Crystallite size and crystalline content decreased through the drop in quartz, mullite and iron oxide of Fly F ash.

Table 3. Important IR Bands, (Patil and Anandhan, 2012)

\begin{tabular}{|l|l|}
\hline Band $\left.\mathbf{( c m}^{-1}\right)$ & Band Assignment \\
\hline $3700-3400$ & OH stretching of Si-OH group \\
\hline 1643 & OH stretching \\
\hline $750-800$ & Si-O-Si symmetric stretching \\
\hline $550-600$ & Si-O-Al stretching \\
\hline 485 & Si-O-Fe stretching \\
\hline
\end{tabular}
amounts and an increase in amorphous phase 
Patil and Anandhan (2012) showed that the peak at $1092 \mathrm{~cm}^{-1}$ has broadened in min using milled FA compared to fresh FA, which is Si-O-Si stretching (Saha, 2018). The peak intensity used to be increased with rising milling time as a proof for the breaking down of the quartz shape and formation of $\mathrm{Si}-\mathrm{OH}$ group (Antoni and Hardjito, 2015). XRD patterns indicated no alternate in the mineralogy and peak intensities in the samples milled up to 60 min, however, a mild minimize in peak intensity and broadening of quartz and mullite was once observed in ninety min milled fly ash (Kumar and Kumar, 2011; Patil and Anandhan, 2012). The milling consequences confirmed adjustments in the peak of IR intensity corresponding to $\mathrm{Si}-\mathrm{O}-\mathrm{Si}$ bending $(460 \mathrm{~cm}-1), \mathrm{T}-\mathrm{O}-\mathrm{Si}(\mathrm{T}=\mathrm{Si}, \mathrm{Al})$ and asymmetric stretching (913, 1090and $1160 \mathrm{~cm}-1)$. The Si-O-Si symmetric stretching band found at $798 \mathrm{~cm}^{-1}$, which was once almost absent in the untreated ash, seemed after the forty five and 60 min. Their XRD outcomes and IR spectra indicated that the impact of milling on fly ash extends beyond new surface creation due to particle breakage and it undergoes structural adjustments via mechanical activation (Sharma et al., 2015). Patil and Anandhan (2015) determined that Si-O-Si symmetric stretching band located at $798 \mathrm{~cm}^{-1}$ of IR intensity in the milled fly ash samples. This band was once absent in unavtivated fly ash and commenced to show up after the milling from 5 to $60 \mathrm{~min}$, which verifies the amorphous segment existence. Kumar and Kumar (2011) indicated that the milling of fly ash harms the crystalline shape which regarded in the minimization of quartz and mullite after milling to ninety min. Patil and Anandhan (2012) investigated the pozzolan activity of fly ash as a characteristic of the extent of bounded $\mathrm{Ca}(\mathrm{OH})_{2}$ with fly admixture after 30 days. There was once a formation of calcium silicates and aluminosilicates (C-S-H and C-S-A-H phases) with a low $\mathrm{CaO} / \mathrm{SiO}_{2}$ ratio in the course of the response process. The interaction between fly ash and $\mathrm{Ca}(\mathrm{OH})_{2}$, used to be grown as a characterization of higher reactivity. Mechanical activation results in slight increase the silica percentage, indicating the amorphous nature. The proportion of alumina reduces and the share of silica improved.Transformation of quartz phases into a glassy phase is faster in MA (Sharma et al., 2015). This means that the mechanical activation extended to create new surfaces due to particle breakage. So the utilization of fly $\mathrm{F}$ in cement geotechnical and Nano solid application will improve due to the amorphous nature, pozzolanic phases that approves to be appeared after milling (Gabor, 2016; Hela and Orsakova, 2013).

\section{Conclusion}

In this paper, mechanical activation of fly $\mathrm{F}$ ash through milling was reviewed. Four milling equipment, Rod, Ball, Eccentric Vibratory and electromagnetic mills can be used to reduce the particle size from coarse to ultra-fine size. The milling time was shorten when higher energy mill was used/applied. Milling or grinding process increases the fly ash reactivity and pozzolanic action. The importance of higher amount of fly $F$ to be utilized in cement replacement, geopolymer and Nano particles applications. The drawback of fly ash F, particularly low strength in early concrete admixture, and low reaction rate in geopolymer had been resolved. In spite that the effect of milling alone did not have sufficient research studies in the adsorption process, since its applied with other activation methods like acidification and alkalization .Modification of fly ash surface properties and morphology, can enhance the application of fly ash to be a valuable commercial products.

\section{References}

Akinrotimi, O. A., Abu, O. M. G., Ansa, E. J., Edun, O. M., Antoni, S. V., and Hardjito, D. 2015. Simple mechanical beneficiation Method of Coarse Fly Ash with High LOI for Making HVFA Mortar. Civil Engineering Dimension, 17(1): 38-43.

Babel, S. and Kurniawan, T. A. 2003. Various treatment technologies to remove arsenic and mercury from contaminated groundwater: an overview. In: Proceedings of the First International Symposium on Southeast Asian Water Environment, Bangkok, Thailand, 24-25 October: 433-440.

Bouzoubaa, N., Zhang, M. H., Bilodeau, A., Malhotra, V. M. 1997. The effect of grinding on the physical properties of fly ashes and a portland cement clinker. Cement Concrete Research, 27(12): 1861-1874.

Brook R. J. 1991. Concise encyclopaedia of advanced ceramic Materials. UK: Pergamon Press Plc.

Coulson and Richardson, 2002. Particle technology and Separation Processes. Chemical Engineering, 2: 117-127. 
Gabor, M. 2016. Mechanical activation of power station fly ash by grinding- A review, Journal of Silicate Based and Composite Materials, 68(2): 56-61.

Hela, R. and Bodnarova, L. 2013. Observation and experience of using mechanically activated fly ash in concrete.

World Academy of Science, Engineering and Technology, International Journal of Civil and Environmental Engineering 7: 11.

Hela, R. and Orsakova, D. 2013. Mechanical Activation of Fly Ash. Concrete and Concrete Structure, 87-93.

Kumar, R., Kumar, S. and Mehrotra, S. P. 2007. Review Towards sustainable solutions for fly ash through mechanical activation. Resources, Conservation and Recycling, 52: 157-179.

Kumar, S. and Kumar, R. 2011. Mechanical activation of fly ash: Effect on reaction, structure and properties of resulting geopolymer. Ceramic International,: 533-541.

Masuda, H., Higashitani, K. and Yoshida, H. 2007. Powder technology: handling and operations, process instrumentation, and working hazards. CRC Press, Taylor and Francis Group, LLC.

Matsuoka, K., Yokoyama, K., Okura, K., Urayama, N., Ueda, M. and Naito, M. 2019. Synthesis of Geopolymers from Mechanically Activated Coal Fly Ash and Improvement of Their Mechanical Properties. Write journal name, 9(12): 791.

Nalbantoglu, Z. 2004. Effectiveness of Class C fly ash as an expansive soil stabilizer. Construction and Building Materials, 18: 377-388.

Palomo, A., Grutzeck, M. W. and Blanco, M. T. 1999. Alkaliactivated fly ashes a cement for the future. Cement Concrete Research, 29(8): 1323-1329.

Patankar, S. V., Jamkar, S. S. and Ghugal, Y. M. 2012. Effect of sodium hydroxide on flow and strength of fly ash based geopolymer mortar. Journal of Structural Engineering, 39(1): 7-12.

Patil, A. G. and Anandhan, S. 2012. Ball Milling of Class-F Indian Fly ash obtained from a Thermal Power Station. International Journal of Energy Engineering, IJEE, 2(2): 57-62.

Patil, A. G. and Anandhan, S. 2015. Influence of planetary ball milling parameters on the mechano-chemical activation of fly ash. Powder Technology, 281: 151-158.
Paul, K. T., Satpathy, S. K., Manna, I., Chakraborty, K. K. and Nando G. B. 2007. Preparation and Characterization of Nano structured Materials from Fly Ash: A Waste from Thermal Power Stations, by High Energy Ball Milling. Nanoscale Research Letter, 397-404.

Paya, J., Monzo, J., Borrachero, M. V. and Peris, E. 1995. Mechanical treatment of fly ashes. Part I: Physico-chemical characterization of ground flyashes. Cement Concrete Research, 25(7): 1469-1479.

Rosenberg, A. 2020. Using Fly Ash in Concrete. https://precast.org/2010/05/using-fly-ash-in-concrete/,19.6.

Saha, A. K. 2018. Effect of class F fly ash on the durability properties of concrete. Sustainable Environment Research, 28: 25-31.

Sanytsky, M., Rusyn, B., Halbiniak, J. and Szymanska, J. 2013. Influence of ultrafine ground fly ash on the microstructure and properties of cementitious materials. Journal of Silicate Based and Composite Materials 2(12): 96-102.

Sharma, S., Kabra, S., Katara, A. and Rani, 2015. Variation of Surface Morphology and Physicochemical Properties of the Fly Ash Through Mechanical and Thermal Activations. Journal of Advanced Chemical Sciences, 1(2): 60-74.

Subhash ,V., Patankar, Yuwaraj, M. G. and Jamkar, S. S. 2014. Mix Design of Fly Ash Based Geopolymer Concrete. Advanced in Structure Engineering,: 1619-1634.

Sushant, S. and Archana, K. (2013). Method of Size Reduction and Factor Affecting Size Reduction in Pharmaceutics. International Research Journal of Pharmacy, 4(8): 57-64

Varma, G., Singh, R. K. and Sahu, V. 2013. A review comparative study on the removal of heavy metals by adsorption using fly ash and sludge. International Journal of Application or Innovation in Engineering \& Management (IJAIEM), 2(7): 45-56

Wołosiewicz-Głab, M., Foszcz, D. and Gawenda, T. 2015. Analysis of possibilities of obtaining the fine particle size in mills of various designs, MEC2015: Mineral Engineering Conference: 14-17.

Wolosiewicz-Glab, M., Foszcz, D., Gawenda, T. and Ogonowski, S. 2016. Design of an Electromagnetic Mill. Its Technological and Control System Structures for Dry Milling. E S Web of Conferences 3: 8-10.

Xue, J. M., Zhou, Z. H. and Wang, J. 2004. Nanocrystalline Ceramics by Mechanical Activation, National University of Singapore, 6: pp.417-433. 